\title{
Historické souvislosti a současnost vzdělávání studentů se specifickými potřebami se zaměřením na praxi Univerzity Pardubice
}

\section{Historical Context and the Current Situation of Education of Students with Specific Needs, focusing on a Practice at the University of Pardubice}

\author{
Zdenka Šándorová1, Fakulta filozofická, Univerzita Pardubice, Pardubice
}

\begin{abstract}
Abstrakt
Uvedeným příspěvkem autorka reaguje na historické souvislosti a současnou situaci servisních opatření, podpory a pomoci studentům se specifickými potřebami na vysokých školách. Cílem příspěvku je zdokumentovat historii vzdělávací inkluze studentů se specifickými potřebami se zaměřením na konkrétní př́klad dobré praxe Univerzity Pardubice. Autorka přistupuje ke zpracování př́spěvku z pozice základního teoretického př́stupu, který je směrován na teoretické objasnění sledovaných jevů. Při zpracování odborného článku byla metodologicky využita: a) obsahová analýza legislativních norem, strategických dokumentů aktuálně platných v ČR a dostupných odborných pramenů; b) kvantitativní design při zpracování statistických přehledů = počet studentů se specifickými potřebami (SP) na Univerzitě Pardubice (UPa) v letech 2012-2021.
\end{abstract}

\section{Klíčová slova}

vzdělávací inkluze, vysokoškolský student, Univerzita Pardubice, legislativní dokumenty

\section{Abstract}

In this paper, the author responds to the historical context and the current situation of service measures, support and assistance for students with special needs at universities. The aim of the paper is to document the history of educational inclusion of students with specific needs, focusing on a specific example of good practice at the University of Pardubice. The author approaches the paper from the position of a basic theoretical approach, which is directed towards theoretical clarification of the observed phenomena. The following methodological approaches were used in the preparation of the paper: a) content analysis of legislative norms, strategic documents currently in force in the Czech Republic and available professional sources; $b$ ) quantitative design in the preparation of statistical surveys = number of students with specialneeds (SP) at the University of Pardubice(UPa)in2012-2021. Theabstract, as written above in Czech, translated into English.

\section{Keywords}

educational inclusion, university student, University of Pardubice, legislative documents

\section{1 Úvod}

Strategie vysokoškolského vzdělávání je v každé společnosti určena společenským, politickým, ekonomickým a kulturním vývojem. Ještě ke konci minulého století bylo vysokoškolské vzdělání dostupné poměrně malé skupině, ale v posledních dvou desetiletích v Evropě i v České republice (po sametové revoluci) se situace začala měnit.

Česká republika v souladu s Všeobecnou deklarací a mezinárodními pakty o lidských právech, Evropskou chartou lidských práv, Úmluvou o právech dítěte, Ústavou České republiky a Listinou základních práv a svobod se ztotožňuje s pojetím, které považuje vzdělání za jedno ze základních lidských práv poskytovaných

1Zdenka Šándorová: zdenka.sandorova@upce.cz 
všem lidským bytostem bez rozdílu a vyhlašuje je za nezcizitelnou a univerzální lidskou hodnotu. „Cíle vzdělávání musí být odvozovány jak z individuálních, tak i společenských potřeb. Nevztahuje se jen na vědění a poznávání, tedy k rozvíjení rozumových schopností, ale i k osvojování si sociálních a dalších dovedností, duchouních, morálních a estetických hodnot a žádoucích vztahů k ostatním lidem i ke společnosti jako celku, k emocionálnímu a volními rozvoji, v neposlední řadě pak ke schopnosti uplatnit se v měnících se podmínkách zaměstnanosti a tím i trhu práce." (MŠMT ČR, Východiska a předpoklady rozvoje vzdělávací soustavy, 2002. In. Bílá kniha, 2001)

\section{Vývoj vysokoškolského vzdělávání studentů se specifickými potřebami v České republice}

Současná praxe vysokoškolského vzdělávání studentů se specifickými potřebami v České republice kontinuálně navázala na již ověřenou inkluzivní praxi předškolního, základního a sekundárního vzdělávání. Za velmi významný dokument v oblasti vysokoškolské inkluzivní politiky můžeme považovat Bílou knihu v terciárním vzdělávání (dále jen Bílá kniha), což potvrzuje nap̌̌. Čerešňová a kol. (2018).

Bílá kniha je určena hlavním aktérům terciárního vzdělávání i široké veřejnosti a její publikace není konečným cílem. Je pouze dílčím výstupem procesu, který stanovuje směry a mantinely další práce včetně změn v oblasti diverzifikace vzdělávacích systémů, nových konceptů řízení (na národní i institucionální úrovni) či finanční spoluúčasti studentů. (Matějůn, 2009 a Bílá kniha, 2009, dostupné z: https://iforum. cuni.cz/IFORUM-6646-version1-BKTV_finalni_verze.pdf)

Pokud analyzujeme referenční pole vysokoškolských studentů se specifickými potřebami v Bílé knize, pak v souladu s požadavkem na posílení mechanismů integrace zdravotně postižených studentů Bílá kniha navrhuje pro tyto skupinu zejména „adekvátním způsobem navýšit základní studijní grant a reflektovat tak skutečnost, že tito studenti mají v důsledku svého postižení zvýšené náklady spojené se studiem“ (2009. s. 60), Bílá kniha také poukazuje na „prevenci“ sociální bariéry v př́istupu k vysokoškolskému vzdělání, a to formou sociálních stipendií.

V Bílé knize je kladen důraz na to, že vysoká škola musí být autonomním a sebevědomým subjektem, jedním z nejdůležitějších prvků občanské společnosti, který díky své autoritě a prestiži může mnoho ovlivnit. Pozitivní role vysokých škol v rozvoji moderní občanské společnosti je tedy neoddiskutovatelná.

Na Bílou knihu navázaly také významné výzkumy, mezi kterými můžeme uvést např. „Analýzu současné situace studentů se specifickými nároky na vysokých školách“, kterou zpracovala na zakázku pro Ministerstvo školství mládeže a tělovýchovy, Odbor vysokého školství společnost Alevia, s.r.o. z roku 2010.

Tato studie měla za úkol vypracovat analýzu současné situace studentů se specifickými nároky na vysokých školách. Zaměření obsahu se koncentrovalo na níže uvedené oblasti:

„Popis současného stavu na vysokých školách v zajištění studia studentů se specifickými nároky na všech veřejných a soukromých vysokých školách (počty studentů dle různých nároků studijních programů, technické a materiální vybavení vysoké školy pro studenty se specifickými nároky, služby poskytované těmto studentům apod.).

- Analýza finanční náročnosti a možných zdrojů financování specifických nároků studentů

- Analýza legislativních předpisů (včetně vnitřních předpisů vysokých škol) vztahujících se k problematice studentů se specifickými nároky

- Doporučení pro vysoké školy a instituce státní a veřejné správy

Dále bylo zadavatelem upřesněno, že pro účely zakázky se „specifickými nároky“ se rozumí nároky studentů s pohybovým, smyslovým, psychickým, kognitivním a jiným zdravotním postižením a jejich kombinace. Termín specifické nároky, který byl použit v rámci zadání veřejné zakázky, byl po domluvě se zadavatelem a v souladu s ustálenou terminologií v analýze nahrazen termínem specifické potřeby (SP), popřípadě souslovím specifické vzdělávací potřeby (SVP) a zdravotní postižení (ZP). Všechny výše uvedené výrazy jsou vnímány jako synonyma.

Zpracovatel dále vycházel ze skutečnosti, že „některá zdravotní postižení automaticky nevyžadují specifické vzdělávací potřeby. Dále je brána v úvahu skutečnost, že specifické vzdělávací potřeby mohou vyplývat i z jiných důvodů, než je zdravotní postižení - důležitou roli hrají i faktory sociální a ekonomické“. Pro potřeby této analýzy však byla věnována pozornost pouze osobám se zdravotním postižením“. 
Dále můžeme upozornit na „Strategii systémového zpřístupňování vysokoškolského vzdělávání studentům se zdravotním postižením“ (dokument schválen na zasedání Vládního výboru pro zdravotně postižené občany, 2010) dostupné z Strategie_VS-ZdP_VVZP0_27.05.2010 (vlada.cz) (dále Strategie).

Strategie je v souladu se zněním Čl. 24, odst. 5 Úmluvy o právech osob se zdravotním postižením, zohledňuje charakteristické znaky vysokoškolského vzdělávání jako součásti terciárního vzdělávání, naplňování uvedeného článku Úmluvy v oblasti vysokoškolského vzdělávání byla realizace těchto cílů: Legislativa, Podpůrná opatření, Hodnocení a kvalita v rámci vysokoškolských institucí, Poradenská centra na VŠ, Metodická podpora pedagogů a dalších zaměstnanců a institucionální podpora.

Následovaly další projekty jednotlivých vysokoškolských pracovišté, např. studie Zezulkové, Novohradské, Kovářové a Kaleji z Ostravské univerzity - Studenti se specifickými vzdělávacími potřebami na vysoké škole (2013) nebo Michalíkova a Škurkova (2014) Právní úprava studia studentů se specifickými potřebami na UP v Olomouci. Autoři se zaměřili zejména na vzdělávání jako základní lidské právo, které je chráněné mezinárodními lidskoprávními dokumenty a právním řádem České republiky.

Také Univerzita Pardubice participovala a aktuálně participuje na zajištění a implementaci inkluzivních podmínek pro studenty se specifickými potřebami. Např. Šándorová(2014) analyzovala v příspěvku Čtyřleté praktické zkušenosti v oblasti vzdělávání a podpory studentů se specifickými potřebami na Univerzitě Pardubice. V následující kapitole popíšeme historické souvislosti vzniku poradenských pracovišt' na Univerzitě Pardubice.

\section{Počátky inkluzivního vzdělávání na Univerzitě Pardubice}

Z hlediska naplnění práv přístupu k vysokoškolskému inkluzívnímu vzdělání také Univerzita Pardubice reagovala na impulsy pro start v terciárním vzdělávání, které definovala Hanousková s Peňázem (in Čerešňová a kol., 2018).

České vysoké školy začaly v devadesátých letech 20. století využívat evropské fondy na renovování svých prostor a odstraňování fyzických bariér. Došlo k rozvoji oddělení pro výzkum a vzdělávání v oboru speciální vzdělávání. Ačkoli jejich cílem byla příprava a vzdělávání učitelů pro inkluzivní vzdělávání na základních a středních školách, byly také spojeny se vznikem prvních poradenských center. Po jejich vzoru se stala pedagogicko-psychologická poradenská centra standardem i na vysokých školách, což vyústilo v založení Asociace vysokoškolských poradců (AVŠP). Nastal rozvoj servisních středisek, která nejprve poskytovala technologické služby (České vysoké učení technické v Praze, Masarykova univerzita v Brně, Univerzita Palackého v Olomouci, Univerzita Hradec Králové). V návaznosti na již jmenované aktivity vznikl důležitý dokument Metodický pokyn MŠMT Financování zvýšených nákladů na studium studentů se specifickými potřebami. Je každoročně vydáván od roku 2011. V souvislosti s ním postupně vznikala servisní centra na ostatních vysokých školách a byla založena Asociace poskytovatelů služeb studentům se specifickými potřebami na vysokých školách (AP3SP), která sleduje naplňování metodického pokynu a každoročně zveřejňuje statistiky o počtu studentů s postižením na vysokých školách. Myšlenka základního studijního grantu definovaného v Bílé knize terciárního vzdělávání byla využita v rámci operačních programů Evropského sociálního fondu v letech 2011-2015, které nabídly českým vysokým školám finanční prostředky a tím možnost odstranit hlavní bariéry ve fyzickém prostředí a také vybudovat technologicky zabezpečená servisní centra, což byla a je nezbytná podmínka pro čerpání finančního příspěvku MSMT. Aktuálně je finanční zajištění zvýšených nákladů obsaženo v Pravidlech pro poskytování příspěvku a dotací veřejným vysokým školám Ministerstvem školství, mládeže a tělovýchovy, konkrétně v Př́loze č. 3 v Metodickém pokynu k financování zvýšených nákladů na studium studentů se specifickými potřebami.

Univerzita Pardubice realizovala od akademického roku 2011/2012 v projektu „Univerzita Pardubice a kampus bez bariér“ aktivity, které byly zaměřeny na podporu, pomoc a poradenství studentů se SVP. Projekt byl realizován v rámci Operačního programu Vzdělávání pro konkurenceschopnost (OPVK IP - Oblast podpory 2.2).

Jako výchozí strategické dokumenty pro UPa poukazující na nutnost řešit potřeby studentů se SVP byly Národní plán vytváření rovných příležitostí pro osoby se zdravotním postižením na období 2010-2014 a navazující Národní plány podpory rovných příležitostí pro osoby se zdravotním postižením na období 2015-2020 a 2021-2025. Dle těchto dokumentů „, oblasti vysokého školství budou rovné př́ležitosti osob se zdravotním postižením podporovány financováním zvýšených nákladů vysokých škol zpřístupňujících 
studium osobám se specifickými potřebami, projektovým financováním a zahrnutím požadavků na př́istupnost studia do standardů pro institucionální akreditace. Důraz je rovněž kladen na získávání kvalitnějších dat o problémech různých skupin studentské populace a mapování jejich průchodu studiem."

Pokud shrneme význam projektu Univerzita Pardubice a kampus bez bariér, pak projekt naplnil zásadní podporované aktivity Operačního programu Vzdělávání pro konkurenceschopnost. Při vytváření a realizaci studijních programů se zapojili odborníci z praxe, inovace přesáhly rámec jednoho studijního programu a tím se zvýšila možnost mezioborových studií. Došlo ke zvyšování odborných kompetencí akademických a ostatních pracovníků vysoké školy. Prohloubila se podpora spolupráce vysokých škol se základními a středními školami v rámci poskytování poradenských služeb a podpory talentovaných žáků.

Významnou součástí projektu byl vznik vysokoškolského poradenského centra Akademické poradny Univerzity Pardubice (APUPA). Aktivity této instituce se zaměřily zejména na poskytování různých forem poradenství (psychologického, speciálně pedagogického, sociálního či profesního), zapůjčování kompenzačních a rehabilitačních pomůcek, zprostředkování osobní asistence či dobrovolníků. Aktivity poradenské instituce směřovaly také do oblasti individuální a skupinové terapie a podpory kondice. Na činnost Akademické poradny APUPA navázal činnost od června 2013 (Univerzitní Směrnice č. 3/2013) Referát služeb hendikepovaným (RSH).

Interdisciplinární týmy obou pracovišt byly připraveny pomoci řešit studentům univerzity problémy spojené se samotným studiem, ale i jiné závažné životní situace, které studenta znevýhodňují či výrazně zatěžují. (Šándorová, 2013)

Vhledem k zachování co nejvyšší úrovně samostatnosti, v plné míře uplatnění tělesné, duševní, sociální i profesní schopnosti, tedy plného zapojení do všech aspektů života studentů se SVP, využívá Univerzita Pardubice systém podpory a pomoci a spolupráce s dalšími subjekty, které poskytují v rámci ucelené rehabilitace služby, a to v souladu s regionální politikou. Jedná se o návazné služby zdravotní, sociální, volnočasové, apod. Systém podpory a pomoci uchazečům a studentům se SVP na Univerzitě Pardubice tedy není uzavřeným systémem, ale naopak systémem otevřeným. Úzká je také spolupráce s neziskovými organizacemi, zejména poskytovateli sociálních služeb. (Šándorová, 2013)

Shrneme-li toto sledované období, Univerzita Pardubice se v rámci operačního programu Vzdělávání pro konkurenceschopnost (OPVK IP - Oblast podpory 2.2) zapojila v letech 2012-2015 mezi další akademická poradenská pracoviště, která poskytují podporu, pomoc a poradenství studentům se specifickými vzdělávacími potřebami (SVP). Z hlediska naplnění práv přístupu k vysokoškolskému inkluzívnímu vzdělání v projektu realizovala nezbytné cílené a systémové podmínky pro možnost studia studentům se SVP.

V průběhu čtyř let byly zabezpečeny kvalitní podmínky, podpơrné služby a opatření v oblasti personální, pedagogické, ekonomické i technické. K podpůrným službám patřilo otevření Akademické poradny Univerzity Pardubice (APUPA) a Referátu služeb hendikepovaným. Rozšíření služeb, které Univerzita Pardubice poskytuje, i do oblasti podpory a péče o studenty se SVP patří mezi významné priority rozvoje univerzity. Vytvářením rovných příležitostí se tak přihlásila k principům daných Základní listinou práv a svobod a zařadila se tím mezi vysokoškolská zařízení, jejichž cílem je naplňovat základní požadavky na rovnost přístupu ve vzdělávání.

\section{Aktuální situace}

V průběhu svého vývoje se Referát služeb handicapovaným přejmenoval na Centrum Alma. Centrum navázalo na činnost Referátu a dále se podílelo a podílí na zkvalitnění zázemí studentům se SP a na vytvoření optimálních podmínek pro úspěšné studium.

Vyrovnání studijních podmínek realizovaných Centrem Alma je v současné doprovázeno konkrétní technickou podporou, diagnostikou a dalšími servisními opatřeními a službami dle příslušných směrnic.

Konkrétně na interní směrnici č. 3/2013 Podpora uchazečům a studentům se SP na Univerzitě Pardubice a Směrnici č. 7/2014 Metodický pokyn k podpoře a vyrovnávání podmínek při přijímacím řízení a studiu uchazečů/studentů se speciálními vzdělávacími potřebami na Univerzitě Pardubice navázala směrnice č. 8/2019 Podpora a vyrovnávání podmínek při přijímacím řízení a studiu uchazečỏ/studentů se specifickými potřebami na Univerzitě Pardubice. Směrnice je výsledkem dlouholetých odborných zkušeností interdisciplinárního týmu poradenských pracoviš̌t Akademické poradny Univerzity Pardubice a Centra ALMA. Zásadní dokument obsahuje 8 důležitých částí, a to konkrétně: 
I. úvodní ustanovení týkající se předmětu úpravy péče o studenta, část II. uvádí výklad základních pojmů (cílové skupiny, dokladech o specifických vzdělávacích potřebách, kategoriích znevýhodnění), část III. se zaměřuje na širokou oblast týkající se specifikace služeb, kompenzací a podpůrných opatření, část IV. uvádí přehled organizačního zajištění podpory osob se SP, část V. zahrnuje evidenci dokumentace o osobách se specifickými potřebami zpracování osobních údajů. Část VI. a VII. specifikuje podporu uchazečů při přijímacím řízení a podporu studentů se SP v průběhu studia. Část VIII. obsahuje závěrečná ustanovení.

Systém podpory a pomoci uchazečům a studentům se SVP na Univerzitě Pardubice tedy není uzavřeným systémem, ale naopak systémem otevřeným. Konkrétní spolupráce s regionálními poskytovateli sociálních a souvisejících služeb na území města Pardubic je realizováno v rámci pracovních skupin komunitního plánování města Pardubic. V souvislosti této spolupráce byly úspěšně navázány bližšś kontakty, zejména s organizacemi poskytující velice žádanou sociální službu osobní asistenci. S některými pracovišti byla navázána spolupráce v rámci poradenství v oblasti rehabilitačních a kompenzačních pomůcek, při zajištování zážitkových seminářọ, společné konference, apod. (Šándorová, 2013)

Podstatným ukazatelem o cílové skupině je statistický přehled počtu studentů se specifickými potřebami na Univerzitě Pardubice v letech 2012-2021. Data jsou zpracována dle Pravidel pro poskytování příspěvku a dotací veřejným vysokým školám - MŠMT ČR.

Tab. 1 Přehled počtu studentů se specifickými potřebami na Univerzitě Pardubice v akademických letech 2012-2021 dle jednotlivých kategorií.

\begin{tabular}{|c|c|c|c|c|c|c|c|c|c|}
\hline $\begin{array}{l}\text { Kategorie postižení } \\
\text { studenta }\end{array}$ & $\begin{array}{l}2012 / \\
2013\end{array}$ & $\begin{array}{l}2013 / \\
2014\end{array}$ & $\begin{array}{l}2014 / \\
2015\end{array}$ & $\begin{array}{l}2015 / \\
2016\end{array}$ & $\begin{array}{l}2016 / \\
2017\end{array}$ & $\begin{array}{l}2017 / \\
2018\end{array}$ & $\begin{array}{l}2018 / \\
2019\end{array}$ & $\begin{array}{l}2019 / \\
2020\end{array}$ & $\begin{array}{l}2020 / \\
2021\end{array}$ \\
\hline [A1] Uživatel zraku & 1 & 2 & 2 & 4 & 5 & 3 & 3 & 5 & 8 \\
\hline [A2] Uživatel hmatu/hlasu & 1 & 1 & 1 & 1 & - & 0 & 0 & 0 & 0 \\
\hline $\begin{array}{l}\text { [B1] Uživatel verbálního } \\
\text { jazyka/od } 32016 \text { mluveného } \\
\text { jazyka }\end{array}$ & 1 & 1 & 2 & 6 & 8 & 7 & 7 & 6 & 5 \\
\hline $\begin{array}{l}\text { [B2] Uživatel znakového } \\
\text { jazyka }\end{array}$ & 0 & 0 & 1 & - & - & 0 & 0 & 0 & 0 \\
\hline $\begin{array}{l}{[\mathrm{C} 1] \text { s postižením dolních }} \\
\text { končetin }\end{array}$ & 2 & 2 & 1 & 7 & 8 & 10 & 13 & 12 & 11 \\
\hline $\begin{array}{l}\text { [C2] s postižením horních } \\
\text { končetin }\end{array}$ & 2 & 2 & 2 & 8 & 10 & 11 & 14 & 14 & 12 \\
\hline $\begin{array}{l}{[D] \text { se specifickými }} \\
\text { poruchami učení }\end{array}$ & 1 & 7 & 14 & 21 & 27 & 31 & 34 & 54 & 72 \\
\hline $\begin{array}{l}\text { [E] s poruchou autistického } \\
\text { spektra }\end{array}$ & 2 & 8 & 8 & 3 & 5 & 3 & 5 & 5 & 6 \\
\hline $\begin{array}{l}{[\mathrm{F}] \mathrm{s} \text { jinou psychickou }} \\
\text { poruchou* }\end{array}$ & & & & 6 & 9 & 7 & 13 & 13 & 18 \\
\hline $\begin{array}{l}\text { Počet studentů se SP v roce } \\
\text { celkem: }\end{array}$ & 10 & 24 & 31 & 53 & 55 & 54 & 68 & 87 & 111 \\
\hline
\end{tabular}

* (včetně neautistických neurovývojových poruch) nebo s chronickým somatickým onemocněním. Od roku 2017 s jinými obtížemi (část 2, čl. 3, odst. 9)

V návaznosti na uvedenou tabulku uvádíme pro ilustraci složitosti problematiky kombinaci jednotlivých kategorií.

2012/2013 - evidováno 10 studentů, z toho 1 student s kombinovaným postižením C1, C2.

2013/2014 - evidováno 24 studentů, z toho 2 studenti s kombinovaným postižením C1, C2.

2014/2015 - evidováno 31 studentů, z toho 2 studenti s kombinovanými postiženími a jsou zařazeni do 2 kategorií typu postižení (C1, C2 a D, E)

2015/2016 - evidováno 53 studentů, z toho 11 studentů s kombinovanými postiženími a jsou zařazeni do více kategorií (kombinace: C1, C2; D, C1, C2; A1, B1; D, E, F; C1, C2; D, C1, C2; C1, C2; A1,C1, C2; B1, F; C1, C2; C2, D). 
2016/2017 - evidováno 55 studentů se SP, z toho 13 studentů s kombinovaným postižením, (přičemž celkem je registrováno 72 kombinací postižení: A1, C1, C2; A1, F; B1, C2; C1, C2, D; C1, C2, F; 5 studentů C1, C2; 2 studenti D, F; D, E, F).

2017/2018 - evidováno 60 studentů. Z nichž 54 studentů se SP, z toho 13 studentů s kombinovaným postižením: A1, F; C1, C2, F; D, E, F; A1, C1, C; B1, C2; a 6 studentů C1, C2; 2 studenti C1, C2, D.

2018/2019 - evidováno 68 studentů se SP, z toho 17 studentů s kombinovaným postižením: 9 studentů C1, C2; 2 studenti D, F; po jednom studentovi A1, F; C1, D; C1, C2, F; D, E, F; A1, C1, C2; C1, C2, D.

2019/2020 - evidováno 87 studentů s SP, z toho 18 studentů s kombinovaným postižením: 9 studentů C1, C2; 4 studenti D, F; po jednom studentovi A1, C1, C2; A1, F; C1, C2, D; C1, C2, F; D, E, F.

2020/2021 - evidováno 111 studentů se SP z toho 17 studentů s kombinovaným postižením: 1 student A1,F; 10 studentů C1, C2; 6 studentů D, F; 2 studenti mají trojkombinaci D, E, F.

Z této potřebné statistiky vyplývá, že celkový nárůst počtu studentů se SP je na UPa významný. Někteří studenti mají kombinaci dvou až tří kategorií postižení, což klade značné nároky na zajištění technické, komunikační i sociální bezbariérovosti, a to v součinnosti multidisciplinárního odborného týmu poradenských pracovníků, akademických pracovníků i THP pracovníků UPa. Jedná se o komprehenzivní přístup, který byl dlouhodobě budován a ověřován.

Nyní k jednotlivým kategoriím: Co se týká kategorií studentů se SP, jsou zastoupeni studenti se smyslovým postižením (kategorie postižení A a B), v kategorii postižení studentů s postižením sluchovým studoval na UPa pouze jeden student kategorie B2 - uživatel znakového jazyka. U této kategorie je nutné zaměřit se na problematiku komunikace, přístup k informacím a prostorové orientace.

Zaznamenáváme také významný nárůst studentů s tělesným postižením, a to s postižením dolních i horních končetin (C1 a C2). Technická bezbariérovost, přístup k informacím včetně asistenčních služeb je nezbytnou součástí inkluzivního prostředí pro tuto kategorii studentů.

Podpůrná opatření jsou realizována také pro nejvíce zastoupenou skupinu studentů se specifickými poruchami učení (kategorie D). Důležitá je diagnostika prostřednictvím DysTestu, který byl konstruován pro vysokoškolské studenty. Diagnostika je velmi významným prostředkem pro stanovení možných reedukačních a kompenzačních postupů. K dispozici jsou pro tuto cílovou skupinu technické pomůcky, např. program ClaroRead. Ten je určen studentům, kteří mají potíže při čtení a psaní. ClaroRead čte zobrazený text syntetickým hlasem, zároveň čtený text na obrazovce počítače zvýrazňuje, a propojuje tak mluvenou a psanou podobu slova.

Specifickou skupinu studentů se SP tvoří studenti s poruchou autistického spektra (kategorie E) nejčastěji se jedná o studenty s Aspergerovým syndromem. I tyto studenty UPa eviduje a poskytuje jim pomoc a podporu v interdisciplinární spolupráci odborníků a vyučujících.

Poslední kategorii postižení tvoří studenti s jinými obtížemi (kategorie F), kam patří studenti s psychickými problémy, s narušenou komunikační schopností, s chronickým onemocněním, apod. V souvislosti s touto kategorií postižení vytvořila pracovní skupina Asociace poskytovatelů služeb studentům se specifickými potřebami na vysokých školách (AP3SP) Manuál podpory studentů s psychickým onemocněním na vysoké škole. AP3SP zaštitiuje vznik a šíření mnoha dalších metodik a materiálů k jednotlivým kategoriím, podílí se na supervizních setkáních pracovníků jednotlivých středisek.

Nárůst studentů se SP na Univerzitě Pardubice je významný. Tento stav je možné vysvětlit1) faktem, že vzdělávací inkluze ve společnosti je fenoménem již vžitým, vzdělávací systém České republiky respektuje inkluzi na všech úrovních vzdělávacího systému, २) uchazeči jsou velmi dobře informováni o poradenském systému Univerzity Pardubice, 3) obě pracoviště (APUPA a Centrum ALMA) věnují značnou pozornost osvětovým aktivitám, 4) studenti se SP sami šíŕí dobrou praxi.

Statistickými ukazateli odborný příspěvek uzavíráme.

\section{Závěr}

Sdělené informace v odborném příspěvku analyzují historické souvislosti a současnost vzdělávání studentů se specifickými potřebami se zaměřením na praxi Univerzity Pardubice. V úvodu jsme popsali krátkou historii a tendence směřování „vysokoškolské inkluzivní speciální pedagogiky“ a tyto tendence zdokumentovali na př́kladu Univerzity Pardubice včetně statistických dat.

V průběhu let 2011-2021 jsme sledovali pozitivní vývoj zabezpečování kvalitních podmínek, podpůrných služeb a opatření v oblasti personální, pedagogické, ekonomické a technické pro studenty se specifickými 
potřebami. Rozšiřování a zkvalitňování služeb, které Univerzita Pardubice poskytuje, oblasti podpory a péče o studenty se SP, patří mezi významné priority rozvoje univerzity. Vytvářením rovných příležitostí se tak univerzita hlásí k principům daných Základní listinou práv a svobod a řadí se tím mezi vysoké školy, jejichž cílem je naplňovat základní požadavky na rovnost přístupu ve vzdělávání. Příspěvkem jsme naplnili cíl, tj. zdokumentovali jsme historii vzdělávací inkluze studentů se specifickými potřebami a konkrétně jsme se zaměřili na př́íklad dobré praxe Univerzity Pardubice.

Obecně jsme zdokumentovali, že Česká republika má zájem na tom, aby každá vysoká škola byla autonomním a sebevědomým subjektem, jedním z nejdůležitějších prvkủ občanské společnosti, který díky své autoritě a prestiži může mnoho ovlivnit. Uvědomujeme si, že pozitivní role vysokých škol v rozvoji moderní občanské společnosti je neoddiskutovatelná, protože úroveň vzdělávání, kvalita vzdělávacího systému a především toho, jak společnost dokáže využít tvưrčího potenciálu všech svých členů, se stávají významným činitelem vývoje společnosti. Začátek formuláre

\section{Literatura}

Čerešňová, Z. a kol. (2018) Inclusive higher edication. Praha: Gasset - Allan Gintel.

Evropská strategie pro pomoc osobám se zdravotním postižením 2010-2020: Obnovený závazek pro bezbariérovou Evropu.

Interní směrnice č. 3/2013 Podpora uchazečům a studentům se SP na Univerzitě Pardubice.

Interní směrnice č. 7/2014 Metodický pokyn k podpoře a vyrovnávání podmínek při přijímacím řízení a studiu uchazečů/studentů se speciálními vzdělávacími potřebami na Univerzitě Pardubice.

Interní směrnice č. 8/2019 Podpora a vyrovnávání podmínek při přijímacím řízení a studiu uchazečů/studentů se specifickými potřebami na Univerzitě Pardubice.

MŠMT ČR Pravidla pro poskytování příspěvku a dotací veřejným vysokým školám Ministerstvem školství, mládeže a tělovýchovy, Příloha č. 3 (Metodický pokyn k financování zvýšených nákladů na studium studentů se specifickými potřebami) 2012-2020.

Matějů, P. (2009) Bílá kniha terciárního vzdělávání. Praha: Ministerstvo školství, mládeže a tělovýchovy. Dostupné z: www.msmt.cz/bila-kniha/otazky-a-odpovedi-k-tezim-bile-knihy-terciarniho-vzdelavani.

Michalík, J. \& Škurek, M. (2014) Práoní úprava studia studentů se specifickými potřebami na UP v Olomouci. Olomouc: Univerzita Palackého v Olomouci.

Národní plán vytváření rovných příležitostí pro osoby se zdravotním postižením na období 2010-2014 (2010). Schválený usnesením vlády České republiky ze dne 29. března 2010 č. 253. Praha: Úřad vlády České republiky, sekretariát Vládního výboru pro zdravotně postižené občany. ISBN ISBN978-807440-024-7.

Národní plán podpory rovných příležitostí pro osoby se zdravotním postižením na období 2021-2025: schválený usnesením vlády České republiky ze dne 20. července 2020 č. 761. Praha: Úřad vlády České republiky, 2020. ISBN 978-80-7440-255-5.

Strategie systémového zpřístupňování vysokoškolského vzdělávání studentům se zdravotním postižením (2010) dokument schválen na zasedání Vládního výboru pro zdravotně postižené občany. Dostupné ze Strategie_VS-ZdP_VVZP0_27.05.2010 (vlada.cz).

Šándorová, Z. (2013) Možnosti spolupráce při zajištování služeb a servisních opatření pro studenty se speciálními vzdělávacími potřebami Univerzity Pardubice s poskytovateli sociálních služeb ve městě Pardubice. In Sborník příspěvků z VIII. ročníku mezinárodní konference „Vysokoškolské studium bez bariér“. Liberec: Technická univerzita Liberec, 2014, s. 97-102. ISBN 978-80-7494-066-8.

Šándorová,Z. (2014). Inkluzivní aktivity ve prospěch studentů se SVP na UPa v akademickém roce 2013-2014. In: Pospíšilová, I. (ed.). „Vysokoškolské studium bez bariér“: sborník příspěvků z IX. ročníku mezinárodní konference zaměřené na trendy ve zpřístupňování studia na vysokých školách lidem se zdravotním postižením a specifickými potřebami, 25. - 26. 9. 2014, s. 45-53. Liberec: Technická univerzita v Liberci, 2014, s. 45-53. ISBN 978-80-7494-169-6.

Šándorová, Z. (2015). Čtyřleté praktické zkušenosti v oblasti vzdělávání a podpory studentů se specifickými potřebami na Univerzitě Pardubice. In Sborník z Odborné dvoudenní konference X. ročník „Vysokoškolské studium bez bariér", Technická univerzita Liberec, 17. 9. - 18. 9. 2015, s. 73 - 82. ISBN 978-80-7494-228-0.

Zezulková, E., Novohradská, H., Kovářová, R. \& Kaleja, M. (2013) Studenti se specifickými vzdělávacími potřebami na vysoké škole. 1. Ostrava: Ostravská univerzita v Ostravě. 


\section{Informace o autorech}

\section{PaedDr. Zdenka Šándorová, Ph.D.}

Odborná asistentka, Katedra věd o výchově, Univerzita Pardubice, Fakulta Filozofická Email: zdenka.sandorova@upce.cz 